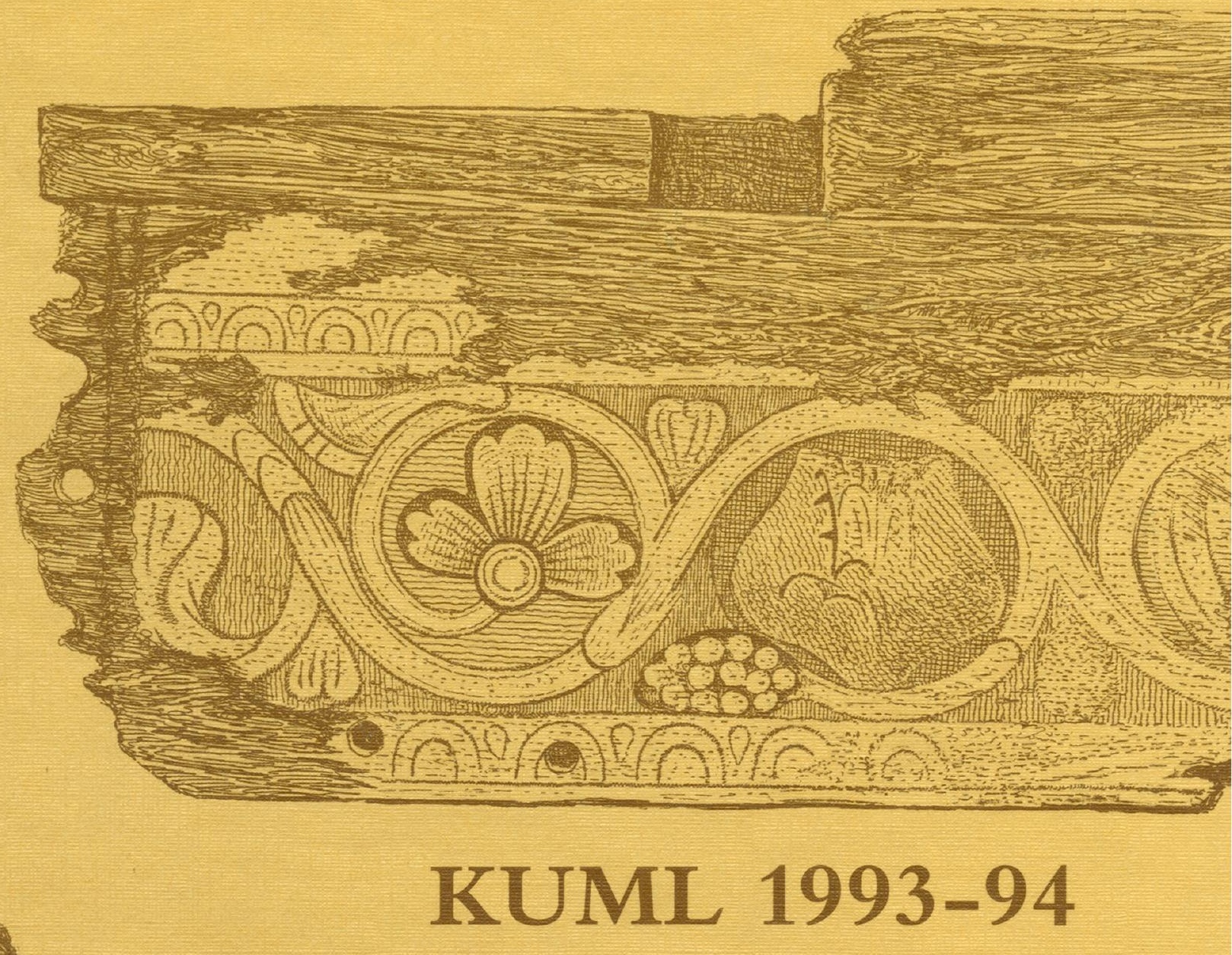




\section{KUML 1993-94}

Årbog for Jysk Arkæologisk Selskab

With summaries in English 
Redaktion: Hans Jorgen Madsen, Poul Kjarum og Birgit M. Rasmussen

Redaktionsudvalg:

Steen W. Andersen, Haderslev

Jens Henrik Bech, Thisted

Steen Hvass, Vejle

Stig Jensen, Ribe

Erik Johansen, Aalborg

Carsten Paludan-Müller, Randers

Ole Schiorring, Horsens

Lay-out og omslag: Jørgen Mührmann-Lund

Grafisk tilrettelagggelse: Elsebet Morville

Tryk: Narayana Press

Skrift: Bembo 11/12

Papir: $115 \mathrm{~g}$ Artik Silk

Copyright 1996 by Jysk Arkaologisk Selskab

ISBN 87-7288-585-8

ISSN 0454-6245 


\section{Indhold/Contents}

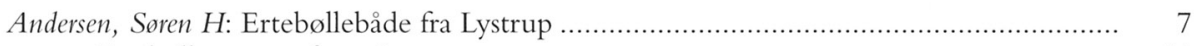

Ertebølle canoes from Lystrup ....................................................................... 36

Ebbesen, Klaus: En jættestue ved Fjersted, Sydvestjylland......................................... 39

A Passage Grave at Fjersted, SW Jutland ................................................... 85

Hansen, Mogens: Træbyggede gravkister fra Enkeltgravskulturen og Senneolitikum ........... 87

Wooden burial cists from the Single Grave Culture and the Late Neolithic .............. 145

Nilsson, Torben: Store Tyrrestrup

En vendsysselsk storgård med bronzedepot fra ældre bronzealder............................ 147

Store Tyrrestrup. A large Early Bronze Age farmstead with bronze hoard .............. 153

Anne-Lonise Haack Olsen og Jens-Henrik Bech. Med bidrag af Svend Th. Andersen,

Pia Bennike, Kjeld Christensen og David Earle Robinson: Damsgård

En overpløjet høj fra ældre bronzealder per. III med stenkiste og ligbrændings-

grube .....

Damsgård. A ploughed-over barrow from Early Bronze Age Per. III with

stone cist and pyre-pit.

Aase Gyldion Andersen: Frugtbarhedsofringer i Sydvestfyns ældre jernalder

Private eller kollektive ofringer?

Fertility Sacrifices in the Early Iron Age of SW Funen. - Private or Collective?..... 210

Torben Egeberg Hansen: Et jernalderhus med drikkeglas i Dejbjerg, Vestjylland .................. 211

Drinking Glasses from an Iron Age settlement from Dejbjerg, West Jutland.............. 237

Mette Iversen og Bjarne H. Nielsen: Brandstrup III.................................................... 239

Grave fra yngre romersk jernalder

Brandstrup III. Graves from the Late Roman Iron Age...................................... 250

Anne Hedeager Krag: Smykkefundet fra Lerchenborg ............................................. 251

Østlige forbindelser i vikingetid

The Lerchenborg Ornaments. Eastern connections in the Viking Age ................ 261

Jens Jeppesen og Holger Schmidt: Rekonstruktion af stavkirken fra Hørning ....................... 263

The reconstruction of the stave church at Hørning ............................................... 275

Bruno Frohlich, Henrik Hjalgrim, Judith Littleton, Niels Lynnerup og Birgitte Sejrsen:

Skeletfundene fra Skt. Peders sognekirkegård i Randers ......................................... 277

Skeletal remains from St. Peder's parish church in Randers .................................. 287

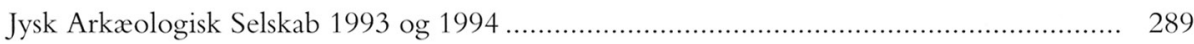




\title{
Rekonstruktion af stavkirken fra Hørning
}

\author{
Af Jens Jeppesen og Holger Schmidt
}

Da kristendommen vandt indpas i Danmark i den sene del af vikingetiden, rejstes de første kirker herhjemme bygget af træ. Disse kirker er nu alle forsvundet, men sporene efter dem er $\mathrm{i}$ adskillige tilfælde påvist, først og fremmest under gulvene i vore stenkirker.

Hvis man i dag vil danne sig et indtryk af trækirkerne, kan en vis viden hentes i de stående norske og svenske stavkirker. Men det må erindres, at de store geografiske afstande samt forskelle i byggetradition, klima og træbestand gør, at der ikke uden videre kan drages paralleller. Desuden er hovedparten af de norske stavkirker bygget efter ca. 1150, hvor de danske trækirker stort set havde udspillet deres rolle. Dermed repræsenterer de nordskandinaviske stavkirker et yngre udviklingstrin end de danske, der hovedsageligt synes at høre hjemme i 1000-årene. En anden kilde til studiet af de danske trækirker fra den sene vikingetid er spredte fund af genanvendt tømmer i stenkirkerne. Disse tømmerstykker synes i nogle tilfælde at stamme fra de pågældende kirkers forgængere af træ (Møller \& Olsen 1961, 35-36).

I Danmark er spor efter trækirker påvist i 10-15 tilfælde. Det beskedne antal kan i høj grad tilskrives fundomstændighederne, idet den meget begrænsede udgravningsflade, man har til rådighed inde $i$ en kirke, altid er præget af omfattende yngre forstyrrelser p.g.a. af begravelser, ombygninger, varmeanlæg m.v. Derfor vil eventuelle spor efter en trækirke oftest være meget mangelfulde, og for med sikkerhed at kunne afgøre, om der er tale om sådanne bygningslevn, er det næsten en forudsætning, at udgravningen omfatter hele kirkegulvet. Så store kirkeundersøgelser er i virkeligheden ret sjældne. Enkelte stolpehuller på-vist ved mere begrænsede afdækninger kan evt. blot være stilladshuller fra opførelsen af den stående kirke.

Trods det ringe antal fund må det dog formodes, at trækirkebyggeriet $i$ 1000-årenes Danmark har været ganske omfattende. I den beskrivelse af Nordens lande som magister Adam af Bremen forfattede omkring år 1070 fortælles, at der i Skåne er 300 kirker, mens der på Sjælland er halvt så mange og på Fyn en tredjedel. Forholdene i Jylland omtales ikke. Disse oplysninger skal naturligvis tages med en del forbehold, men de antyder dog, at der på det tidspunkt fandtes et betydeligt antal kirker i Danmark, og hovedparten af disse må formodes at have været bygget af træ. Kirkebyggeri i sten synes først at have fundet sted i større omfang fra slutningen af 1000-årene (Møller \& Olsen 1961, 35).

Fra de skriftlige kilder ved vi ellers næsten intet om kirkebyggeriet før 1100. Danmark er idag opdelt i omkring 2000 sogne, og den inddeling synes i vid 
udstrækning at være fastlagt allerede i løbet af 1100-årene som en konsekvens af kirketiendens indførelse. Der er almindelig enighed om, at sogneinddelingen ikke kan fores længere tilbage i tid (Blaaberg 1992,15) og dermed sige noget om trækirkebyggeriet. Men en antydning af disse kirkers udbredelse kan måske alligevel ses i omfanget af det tidlige stenkirkebyggeri, idet der i løbet af 1100årene og tiden omkring 1200 blev opført ca. 1700 romanske stenkirker i Danmark (Blaaberg 1992, 44). Det forekommer sandsynligt, at denne intensive byggeaktivitet over hele landet er sket på baggrund af et i forvejen vidt udbredt trækirkebyggeri. At sådanne kirker faktisk har været almindelige her i landet bevidnes af Erik Ejegods (1095-1103) skjald Markus Skegjason. Han lovpriser kongens trækirker, som "i enhver henseende " var »de fineste kirker bygget af træ nord for Sachsen« (Hauglid 1994, 54). Ifølge E. Nyborg har det især været enkeltmandsbyggeriet, der var fremherskende før sogneinddelingen. Konger og bisper har opført centrale, offentlige kirker, mens lokale stormænd har opført kirker til sig selv og deres undersåtter (Nyborg 1979, 41). Denne opfattelse støttes bl.a. af de nylige undersøgelser ved Lisbjerg kirke, hvor udgravningsresultaterne tyder på, at en trækirke har været opført i tilknytning til en stormandsgård fra den sene vikingetid (Jeppesen \& Madsen 1988-89, 289ff; Sørensen, Jeppesen \& Madsen 1995).

\section{Stavkirken i Hørning}

Lige siden slutningen af forrige århundrede har man i Danmark interesseret sig for de tidlige stavkirker (Kornerup 1869, 377ff; Petersen1894, 377ff), men endnu er der ikke bygget en rekonstruktion. På Moesgård har Forhistorisk Museum og Aarhus Universitet påbegyndt et samarbejde med henblik på at opføre en sådan kirke fra vikingetidens slutning, og takket være økonomisk støtte fra Civilingeniør Aage Louis-Hansens Mindefond, kunne byggeriet påbegyndes allerede i foråret 1995. Stavkirken bliver placeret ved Moesgård Museum i forbindelse med de allerede opførte rekonstruktioner af huse fra vikingetiden.

Med henblik på byggeriets gennemførelse er der nedsat en arbejdsgruppe, der blandt de danske fund har peget på stavkirken fra Hørning ved Randers som den mest egnede for rekonstruktionsprojektet. Den blev i 1960 udgravet af Nationalmuseet under gulvet i den nuværende Hørning kirke. Trækirkens grundplan fremstod ret klart med et rektangulært skib, $6 \mathrm{~m}$ langt og 4,5 m bredt samt et nærmest kvadratisk kor, der målte 3,3×3,3 m. Forkullet egetræ i stolpehullerne viste, at den lille trækirke er nedbrændt, og branden har været så voldsom, at den lerede jord omkring stolperne flere steder var stærkt rødbrændt.

De fleste af kirkens stolpehuller var så velbevarede, at de gav et ret præcist billede af det jordgravede tømmers tværsnit (fig. 1). Der har været tale om to typer stolper, hjørnestolper og vægstolper. I skibets fire hjørner og korets østhjørner har stået rektangulære stolper, der målte 20-25 x 35-40 cm. Vægstolperne har haft et femsidet tværsnit og stået med en skarp ryg ind i kirken. Disse stolper, der målte ca. $30 \times 35 \mathrm{~cm}$, har inddelt skibets langvægge i tre og korets sidevægge $i$ to fag.

Kirkens indgangsdør har været placeret midt i skibets vestgavl, og de tilhørende stolpehuller viser, at døren har været ca. 1 meter bred. Der blev kun fundet svage spor af skibets østvæg, triumfvæggen. Af koret blev der fundet spor 


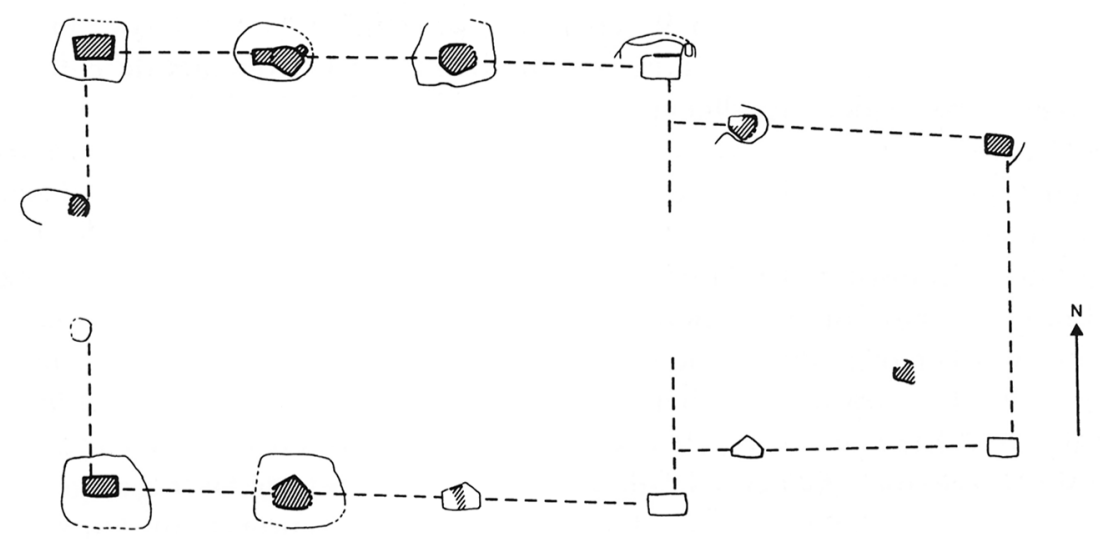

Fig. 1. Plan over stavkirken fra Hørning med spor af det jordgravede tømmer.

Plan of the Hørning stave church showing the traces of the earthfast timbers.

af nordvæggen og østgavlen. To pælehuller inde i koret skal måske sættes i forbindelse med alteret.

Lidt vest for kirken fandtes fire stolpehuller omgivet af et kraftigt brandlag, der indeholdt hundredvis af små malmdråber. Her har sandsynligvis været en fritstående klokkestabel, der også er blevet ødelagt ved trækirkens brand, og metaldråberne viser, at kirkeklokken er smeltet.

Ved udgravningen viste det sig, at trækirken var opført ovenpå en udjævnet gravhøj. Centralt under denne høj fandtes et stort, træbygget gravkammer, der indeholdt en fornem kvindegrav fra vikingetidens slutning, tiden omkring år 1000. Kirken var blevet placeret således, at graven lå under gulvet i skibets vestende umiddelbart indenfor døren. Fundet tolkes på den måde, at den døde kvinde efter hedensk skik er begravet i en høj, men ret kort efter er kirken blevet opført af hendes efterkommere, som ønskede at give hende en kristen begravelse. Det er så sket ved, at man har udjævnet gravhøjen og placeret kirken over graven. Hørningfundet giver dermed måske et glimt af de overvejelser, man har gjort sig i den ældste kristne tid (Krogh \& Voss 1961, 5ff; Gräslund 1992, 141).

Udover de påviste spor i jorden har vi den berømte Hørningplanke, der blev fundet i korets murfyld under restaurering af Hørning kirke i 1887 (fig. 2). Selvom der tidligere har været udtrykt tvivl om, hvorvidt den stammer fra den påviste trækirke (Hauglid 1969, 15), så er der i dag almindelig enighed om, at planken og bygningssporene i jorden hører sammen. Flere ting peger da også i den retning. På Hørningplankens inderside er konstateret svage brandspor, der sandsynliggør, at den tilhører den nedbrændte kirke. Yderligere er der i brandlaget fra denne bygning fundet et lille træstykke med farverester, der svarer til bemalingen på planken (Krogh \& Voss 1961, 17). Formodningen om samhørighed styrkes desuden af en dendrokronologisk datering, der angiver Hørningplankens fældningstidspunkt til 1060-1070 e. Kr. (Arkæologiske ud-. gravninger i Danmark 1990, 234). 
Det bevarede plankestykke er $91 \mathrm{~cm}$ langt, omkring $14 \mathrm{~cm}$ tykt og $55 \mathrm{~cm}$ højt. Det udgør en del af det såkaldte hammerbånd, der har optaget de lodrette vægplanker oppe under tagudhænget. I plankens underside findes en kraftig notrille, hvori vægplankernes øvre ender har været fastholdt. I oversiden ses spor af en nedskæring, og i plankens ene ende er der rester af en tap, hvormed den har været fastgjort til en hjørnestolpe. På ydersiden er hammerbåndet udsmykket med Urnesstilens karakteristiske ormeslyng skåret i skarpt relief. Denne udsmykning er indrammet af henholdsvis en kantprofil ved plankens nedre afslutning og over ormeslynget af en kraftig tovsnoet vulst med en skråt nedskåret notrille. Den oprindelige bemaling er delvist bevaret og viser, at ydersidens bundfarve har været sort. På den baggrund har ormen fremstået med en stærk gul farve og med rødt øje, snude og nakketop. Den røde farve går igen på den nedre kantprofil og på den overliggende vulsts tovsnoning, hvor den veksler med sort. Plankens inderside er glat og her er på kridtbund malet en planteranke i farverne rød, gul, grøn og sort.

Hørningmaterialet udgør således et fund, hvor man ud over de påviste spor $\mathrm{i}$ jorden også har kendskab til vigtige konstruktionsdetaljer takket være det bevarede brudstykke af hammerbåndet. Denne enestående situation er baggrunden for, at netop Hørningstavkirken er blevet udvalgt til rekonstruktionsforsøget.

\section{Rekonstruktionen}

Man kan aldrig lave en "sikker" rekonstruktion af en helt eller delvist forsvunden historisk bygning. Fortolkningen af det overleverede materiale kan endog være særdeles problematisk, og en rekonstruktion er derfor alene af den grund forbundet med både ideologiske og praktiske vanskeligheder. Hertil kommer naturligvis alt det, man ikke kan vide noget om. Det skal derfor fastslåes, at der kun er tale om et forsøg på en rekonstruktion af stavkirken i Hørning, der skal bygges i fuld størrelse.

Grundplanen af den tømmerbyggede kirke og det heldige fund i forrige århundrede af Hørningplanken giver hver for sig meget vigtige oplysninger om den samme længst forsvundne bygning. Hermed er rekonstruktionen hjulpet godt på vej, men alle problemerne er dog langtfra løst. Tværtimod kan man roligt fastslå, at der i forbindelse med projekteringen må træffes en hel række valg, ganske som i enhver anden byggesituation. Det er således indledningsvis helt grundlæggende at fă fastslået, $i$ hvor høj grad man ved udformningen af bygningen og dens dekoration skal lade forsigtigheden råde, da ikke mindst detaljerne vil være af stor betydning for kirkens udseende. Af mere praktisk art er valget mellem udelukkende at anvende datidens byggeteknik (for så vidt vi ellers kender den), eller om vi i nogle tilfælde kan benytte moderne teknik. I den forbindelse skal det nævnes, at det allerede har været diskuteret, om man skal give bygningen et skjult, støbt fundament i stedet for at jordgrave tømmeret. Hermed vil man kunne undgå, at tømmerets nedre ender efter forholdsvis få år skal udskiftes eller netop erstattes af en støbt fundament under bygningen, som det blev gjort for nogle år siden på Trelleborghuset (Schmidt 1981, 138). Det skal i denne forbindelse også nævnes, at alt tømmeret i princippet skal være udkløvet og tilhugget egetræ. Men det er dog ikke givet, at tømrerne, når det kommer til stykket, vil anvende den teknik overalt. I praksis vil rationelle kom- 

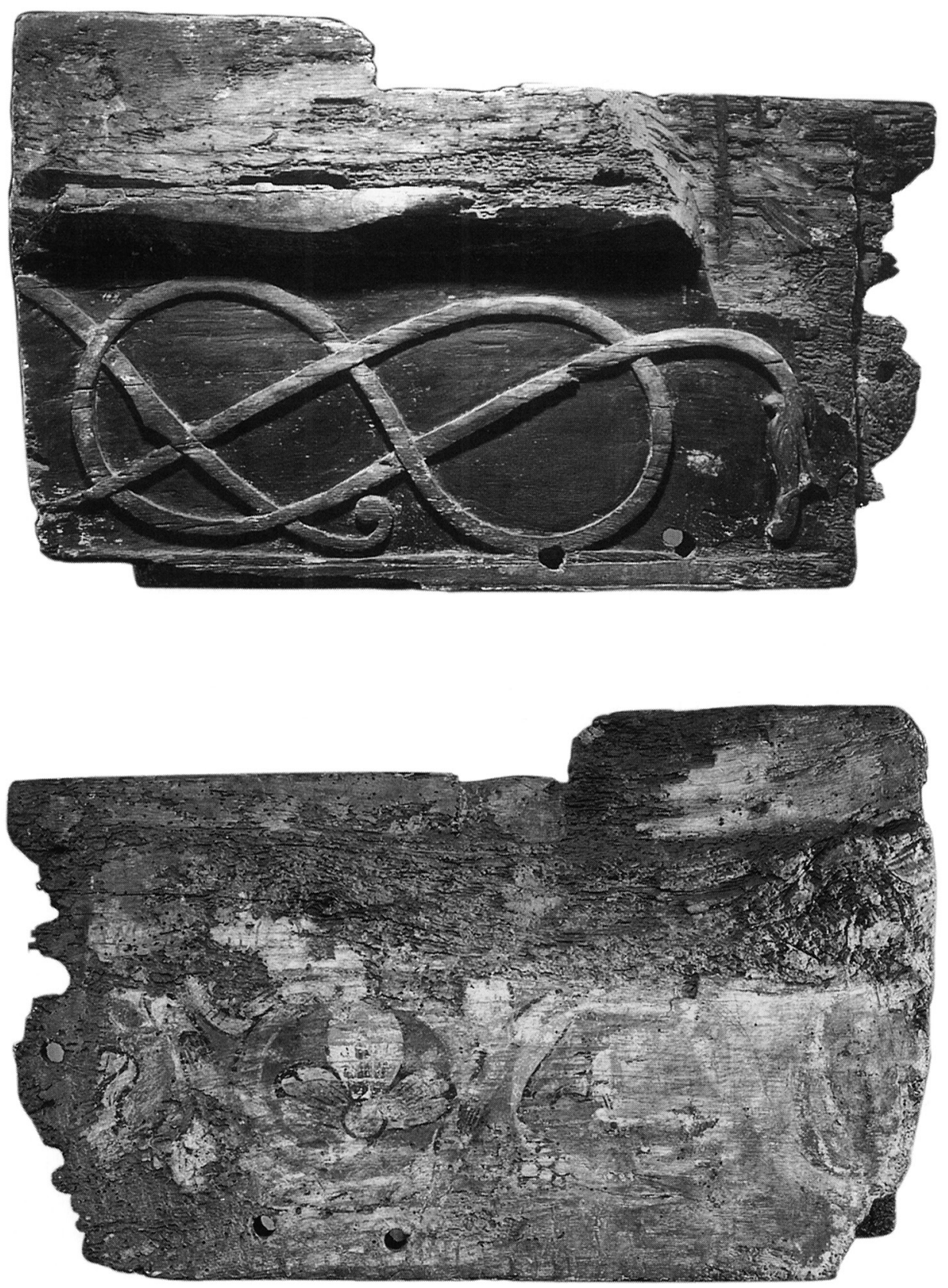

Fig. 2. Det bevarede stykke af Hørningkirkens hammerbånd. De påviste farvespor på ydersiden danner grundlag for den rekonstruerede kirkes ydre bemaling.

The surviving piece of the Hørning hammer-beam. The outside of the reconstructed church will be painted in the same colours as the outer side of the beam. 
promis'er utvivlsomt blive nødvendige, såfremt kirken skal kunne bygges og vedligeholdes uden urimeligt store omkostninger.

Under projekteringen er de mere erkendelsesmæssige problemer selvsagt også særdeles aktuelle - så meget mere som det bl.a. netop er for bedre at forstå de arkitektoniske og konstruktive forhold, at man overhovedet går igang med en sådan opgave. Ved udarbejdelsen af arbejdstegningerne vil der nødvendigvis blive fokuseret på problemer, der ellers næppe var blevet påtrængende. Under arbejdet fremgår det så i nogle tilfælde med stor tydelighed, hvad hensigten har været med den specifikke udformning af både detaljer og helhed. Skønt der bestemt aldrig har været tvivl om, at Hørningplanken repræsenterer en nok så avanceret byggeteknik, stod det forst under projekteringen klart for arkitekten, at det flot skårne ormeslyng på ydersiden har fungeret omtrent som den dekorerede frise i klassisk arkitektur. Dette forhold har bygmesteren i sin tid dog næppe været bevidst om, da det tilsyneladende var almindeligt at dekorere de tidlige tømmerbyggede kirkers hammerbånd på denne måde, som det bl. a. fremgår af irsk bogmaleri i Book of Kells fra 700-årene, jvf. fig. 3 (Henry 1973, colour plate B). At bygningen iøvrigt er disponeret ganske som de romanske stenkirker med et rektangulært skib og et kvadratisk kor må have været et direkte krav fra den kirkelige autoritet. Men det viser alligevel, at man i kirkebyggeriets barndom herhjemme har kombineret en ny stil med en gammel, lokal byggeskik.

Den dengang topmoderne internationale romanske stil har altså delvis bestemt udformningen. Hermed er det også klart, at den i udstrækning såre beskedne bygning må have hævdet sig ved sin klare - næsten prismatisk - kubiske form og sin store væghøjde. Hertil kom dekorationen, hvorved kirken kom til at ligne et af samtidens husformede helgenskrin (Lasco 1972). At det selvfølgelig omvendt var skrinene, der efterlignede kirkerne, er i denne forbindelse uvæsentligt.

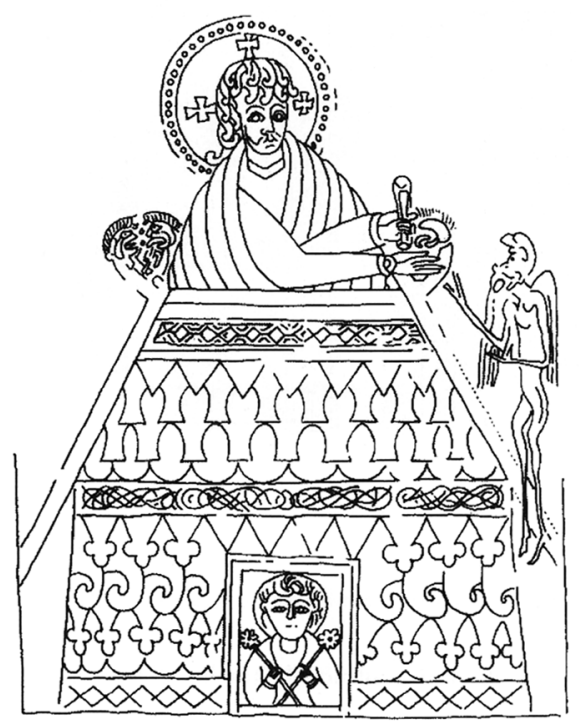

Fig. 3. Tempelfremstillingen i The book of Kells med dekorerede hammerbånd, tagkam og vindskeder.

Painting of temple in the Book of Kells, with decorated hammer-beam, roof ridge, and barge boards. 
Fig. 4. Muiredachs store stenkors på kirkegården i Monasterboice.

The high cross of Muiredach at Monasterboice.

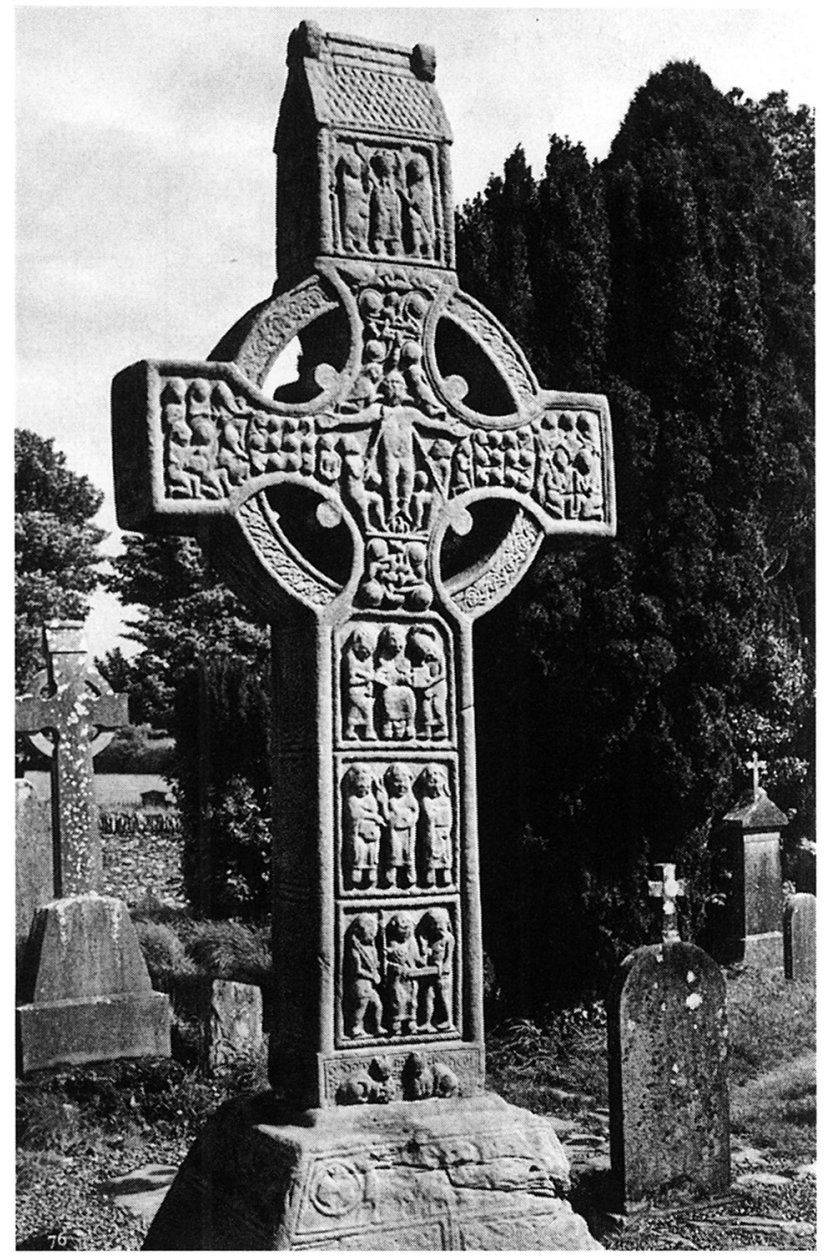

De bedst bevarede fremstillinger af de tidlige, små tømmerbyggede kirker er dog topstykkerne på de store irske stenkors (The High Crosses) fra vikingetiden (Henry 1973, plate 76, 83, 86, 87, 90, 93, 98 og 100). I flere tilfælde er disse topstykker udformet som små skrin eller kirkebygninger, der helt realistisk er søgt karakteriseret ved høje vægge, hjørnestolper, hammerbånd, spånklædte tagflader kronet af en høj kam og dekorerede vindskeder (fig. 4). Netop sådan må kirken i Hørning have set ud, og den var jo også i sig selv et helgenskrin, da den i sit alter rummede en relikvie (Christiansen 1972, VIII).

For at fremhæve kirkens højde placeres den rekonstruerede modelbygning øverst i området bag ved de øvrige rekonstruerede vikingehuse på Moesgård. Det let hævede plateau kan evt. siden udformes som en beskeden kirkegård med tuegrave, gravsten, gravtræer m.v.

Bygningskonstruktionens vigtigste del udgøres af væggenes jordgravede stolper. De danner sammen med de vandrette hammer- og gavlbånd samt fodtøm- 


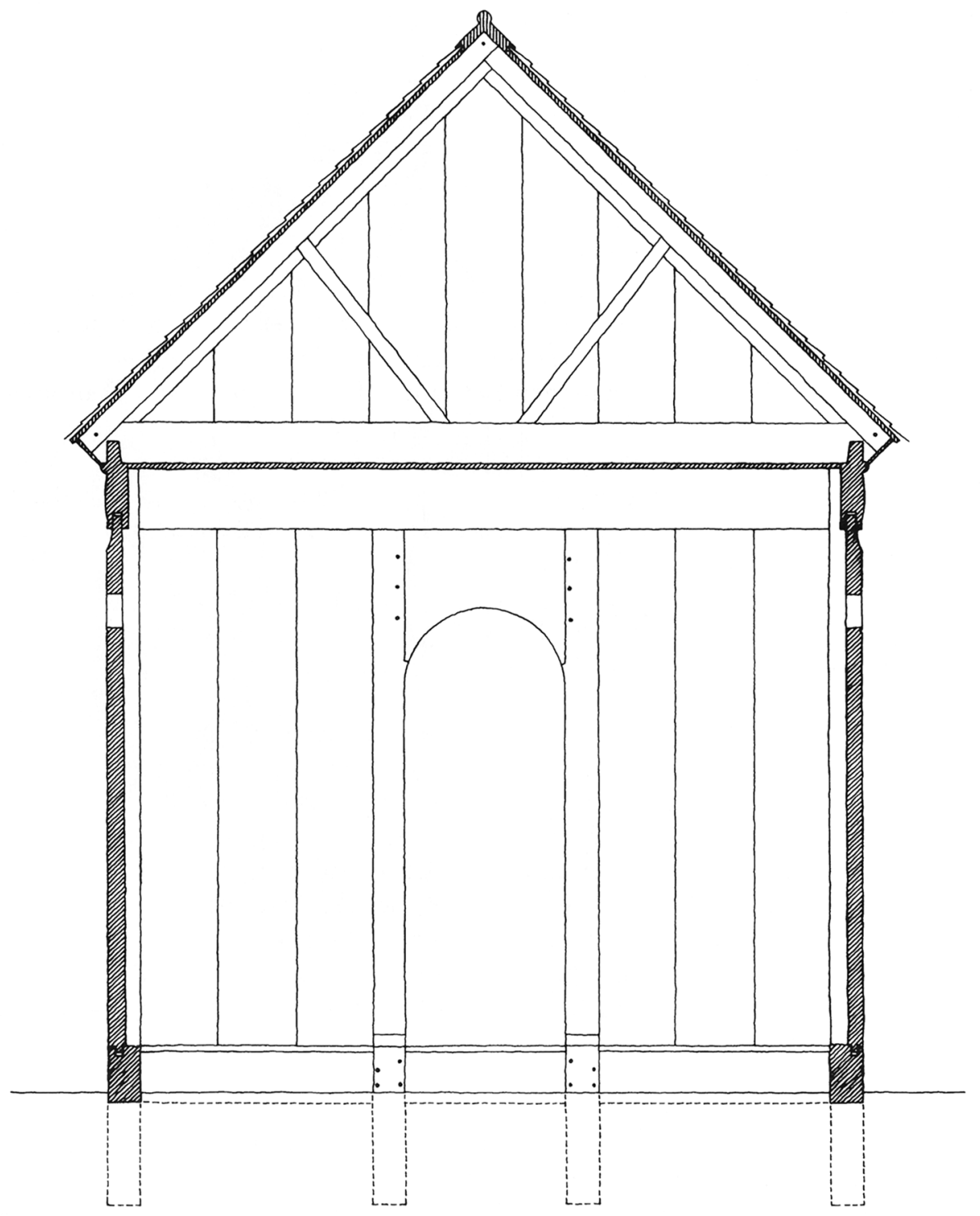

Fig. 5. Tværsnit af stavkirkemodelforslaget. 1:50.

Cross-section of the proposed reconstruction. 1:50.

meret stive rammer både i bygningens længde- og tværretning (fig. 5). Stivheden fremkommer ikke mindst ved, at tømmerstykkerne er samlet med meget brede, fornaglede tappe. Det var ellers alle dage et stort problem at fă stavvæggene stabile i deres længderetning (Krogh \& Voss 1961, 14f), og det blev ikke lettere, da man senere $\mathrm{i}$ tiden opgav at nedgrave stolpeenderne og satte hele konstruktionen op på fodtømmer. Men selve Hørningplankens høje og 
slanke tværsnit mere end antyder væggenes rammesystem, og hammerbåndets højde gjorde det ligefrem nødvendigt at tappe dets ender ind i hjørnestolperne for at undgå, at det kæntrede. Hermed kommer hammerbåndet i realiteten til at hænge i stolperne i stedet for, som god tømrerskik er, at hvile på dem. Måske var også opstillingen af de femkantede, mellemfaldende vægstolper et forsøg på at stabilisere den høje vægrem, hvorfor de i vort forslag støtter hammerbåndets inderside. Som i de norske stavkirker er kor og skib gjort lige høje (Bjerknes 1976, fig. 66), og korets hammerbånd er derfor samlet med skibets østre gavlbånd, hvad der også både konstruktivt og arkitektonisk er den bedste løsning. Da ormeslynget som nævnt danner en omløbende frise, er det iøvrigt indlysende, at hammerbåndene skal placeres i den samme højde $\mathrm{i}$ bygningens to afsnit, så frisen kan omslutte hele bygningen i et samlet forløb kun afbrudt af hjørnestolperne.

Gavltrekanterne er i forslaget også konstrueret med rammer, der her dannes af de vandrette gavlbånd og de skråtstillede spær. Den rent udfyldende del af gavlvæggene dannes som i de øvrige vægge af brede, lodretstillede planker, der fastholdes i rammetømmerets noter.

Vægplankernes tværsnit er omtrent plankonvekst, og tømrerne valgte at samle dem indbyrdes med smalle "løse f fjerplanker. Men også andre løsninger på det udfyldende stavplankesystem kan have været anvendt i Hørning i sin tid (Clemmensen 1937, fig. 298).

Udgravningsresultaterne fra Hørning tyder klart på, at vægplankernes nedre ender har stået $\mathrm{i}$ fodtømmer. Mellem stolpehullerne fra hjørne- og vægstolper fandtes nemlig ingen spor efter jordgravede vægplanker, som det kendes fra Maria Minor stavkirken i Lund (Liebgott 1989, fig. 137). Ved rekonstruktionen bliver fodtømmeret tappet ind i stolpernes sider og jordgravet $\mathrm{i}$ ringe omfang. I oversiden udstemmes en smal not, der skal fastholde vægplankernes nedre ender. Noten bliver et særdeles sårbart punkt i konstruktionen, da indtrængende regnvand uvægerligt vil blive stående $\mathrm{i}$ bunden og bevirke, at tømmeret rådner. Derfor kopieres efter de norske stavkirker løsningen med små, borede afvandingskanaler, der fører vandet ud på stokkenes forside (Bjerknes 1976, fig. 24 og 34).

Hørningplanken er udformet med et stærkt markeret profil på ydersiden bestående af et kantprofil, et hvælvet midtparti med udskæringer og en vulst med snoet motiv. På indersiden er den derimod glat (fig. 2 og 6). Vægplankerne tilstræber ved deres udformning en tilsvarende forskel, d.v.s. en kraftig reliefvirkning i forsiden, som solskyggerne vil fremhæve, og en mere glat inderside.

Den $12 \mathrm{~cm}$ brede nedskæring $35 \mathrm{~cm}$ fra tapenden i Hørningplankens overside (se fig. 2) er det eneste spor, der fortæller lidt om kirkens tagkonstruktion. På dette sted har en bindbjælke været »kæmmet« over vægremmen. Det er givet, at denne bindbjælke har været en af flere, og det er sandsynligt, at de sammen med spærene har dannet stive trekanter, såkaldte spærfag, der har den gode egenskab, at de kun belaster væggene med et lodret tryk og derfor ikke skubber væggene udefter. Denne siden så almindelige tagkonstruktion findes bevaret i adskillige romanske kirker i Danmark (Møller 1953, 136-49). I Garde kirke på Gotland findes under det gotiske tag også det oprindelige romanske tag bevaret (Alsløv m.fl. 1978). De meget fornemt udformede romanske spær i denne kirke er til- 


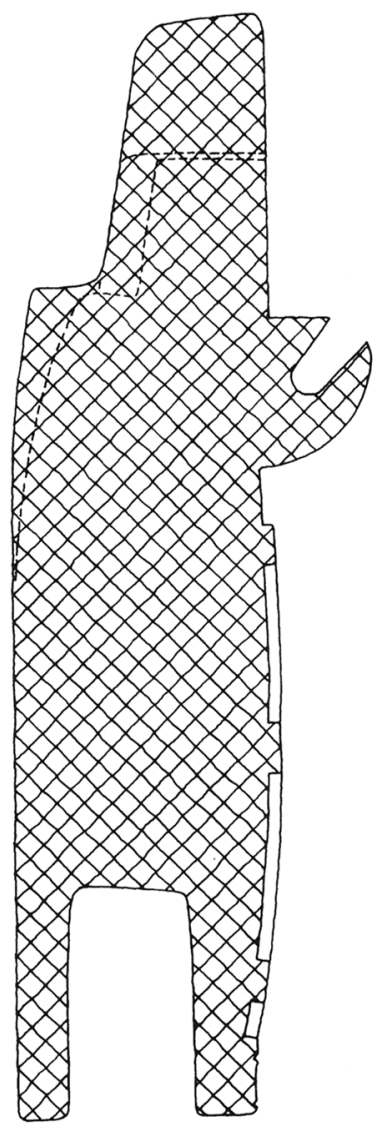

Fig. 6. Tværsnit af Hørningplanken 1:5.

Cross-section of the Hørning hammer-

beam fragment. 1:5.

syneladende genanvendte og stammer måske fra en vikingetidsstavkirke. De er i hvert fald C-14 daterede til år $940 \pm 100$ år (Sveriges kyrkor, Gotland, Garde kirke, 288). Spærfag af romansk type med skrå spærstivere og muligvis også hanebånd er derfor det bedste bud på en rekonstruktion af tagværket på Hørningkirken.

Et tilbagespring på den ellers glatte inderside af hammerbåndet antyder, at der nok har været sømmet et loft på bjælkernes underside (fig. 6). Stykket over tilbagespringet viser nemlig ingen tegn på bemaling og må derfor antages at have været skjult. I så fald har det ikke været muligt at se op i taget inde fra kirkerummet som i de norske mastekirker med åben tagstol.

I Garde kirke er også den romanske tagdækning delvist bevaret. Den består af meget store, tilspidsede egetræsspån oplagt på et bræddeunderlag. Tagkammen, der krones af en vulst med tovsnoning, er ligeledes bevaret, og i vort forslag er spån, bræddeunderlag og tagkam kopieret efter den gotlandske model.

I oversiden af vulsten på Hørningplankens yderside er der udstemt en not for det bræt, sugfjælen, der har lukket tagrummet nederst og beskyttet bjælkeenderne. Denne sugfjæl har ikke, som i de romanske stenkirker, siddet vandret men derimod i en vinkel på ca. $45^{\circ}$. Grunden hertil må være, at man derved 
opnåede, at tagudhænget ikke skyggede for ormeslynget. Ligesom på topstykkerne af de irske kors vil vor kirkemodels tag blive afsluttet med vindskeder ved gavlene.

Som omtalt er der på begge sider af Hørningplanken rester af den oprindelige bemaling, der på ydersiden omfatter rødt og gult på en sort bundfarve. Denne grelle vikingetidsstaffering er naturligvis søgt gennemført i projektet, hvor den udskårne og malede dekoration forsigtigvis er koncentreret til hammerbåndet og portalen. Hørningplankens sorte grundfarve er baggrunden for at male kirken sort med væggenes rammesystem fremhævet ved røde kantprofiler på stolperne svarende til hammerbåndets nedre kantprofil. Den sortmalede kirkebygning foreslåes yderligere udsmykket ved også at male tagspånenes kantprofiler røde ligesom kantprofilerne på vindskeder og tagkam. At den sidstnævntes afsluttende vulst med tovsnoning skal være rød og sort som hammerbåndets vulst siger næsten sig selv (fig. 7).

Med hensyn til bemalingen har kirkens indre været mindre ekspressivt end ydersiden, som det fremgår af hammerbåndets indersidebemaling med en nærmest romansk rankedekoration. Det har under alle omstændigheder været ganske vanskeligt overhovedet at se den malede dekoration i det meget mørke kirkerum. Udsmykningen her har nok først og fremmest været skabt til Guds ære. For det er nemlig givet, at vinduerne kun var ganske små og af cirkulær eller halvrund romansk form. Hertil kommer at de muligvis har været forsynet

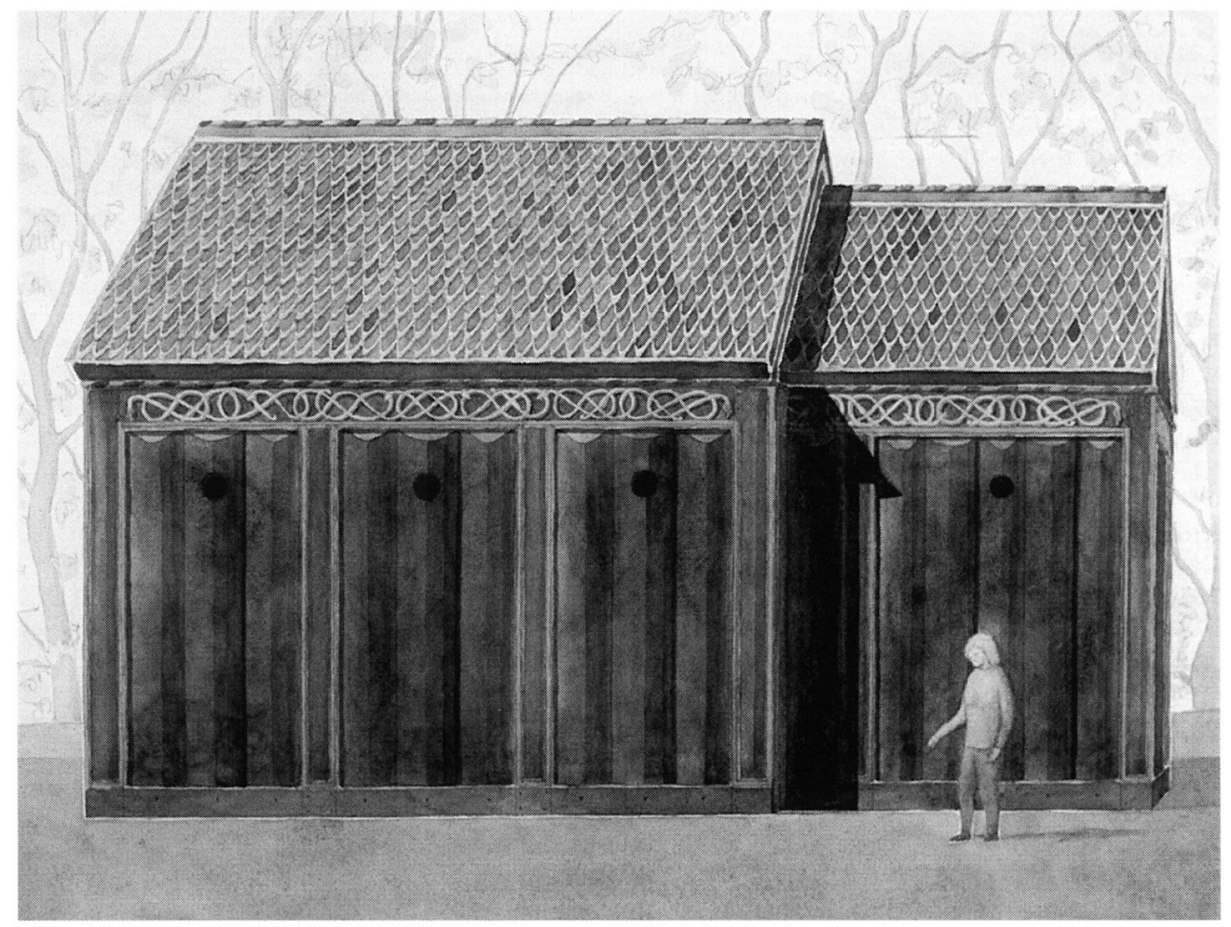

Fig. 7. Forslag til rekonstruktionsmodel i fuld størrelse af Hørningstavkirken.

Proposed full-size reconstruction of the Hørning stave church. 
med farvede glasruder, der yderligere har reduceret mængden af dagslys. Til gengæld skal man ikke undervurdere bidraget til belysningen fra vokslysene. Arkitekten mindes endnu, hvorledes en kæmpestor og bælgmørk kirke i Verona på forunderlig vis blev oplyst af et enkelt vokslys.

$\mathrm{Vi}$ kender intet til kirkerummets indretning. Selv korbuens utvivlsomt meget beskedne bredde kender vi ikke. Formodentlig var gulvet kun et simpelt jordgulv, der rimeligvis var hævet et trin op i koret som i de senere stenkirker. I koret må der nødvendigvis have været opstillet et alter, men om det var af sten (Christiansen 1972, VIII), havde malet eller endog gylden forside (Lasco 1972, pl. 46, 130, 131 og 179) eller var udformet på en helt anden måde, ved vi ikke. Dette alter stod formodentlig under et lille stolpebåret tag, et såkaldt ciborium (se fig. 1). Der har rimeligvis også været et eller flere altre i skibet, og i korbuen hang der sikkert et krucifiks (Norn \& Skovgård 1990, 46 og 49). Fundamenter fra sidealtre, vægbænke og døbefonte bliver regelmæssigt fundet ved udgravninger i de romanske stenkirkers gulve. Vægbænkene kendes også fra de norske stavkirker (Olsen 1967, 235-57). I Hørningkirken kan der have været opstillet en døbefont inden for portalen, ligesom der nok var faste vægbænke i skibet.

Med hensyn til modelkirkens indretning er der dog slet ikke taget beslutninger på nuværende tidspunkt, men det er planen at tage denne opgave op i forlængelse af byggeriet. I arbejdsgruppen håber vi meget, at også spørgsmålet om kirkeinventaret vil give anledning til en livlig debat blandt alle, der er interesserede.

\section{LITTERATUR}

Alsløv, A., J. Ganshorn \& J. Thomsen. 1978: Et romansk tagvark. Garde kirke. København 1978.

Arkcoologiske udgravninger i Danmark 1990.

Bjerknes, K. 1976: Kaupanger Stavkirke og dens konstruktioner. Oslo 1976.

Blaaberg, C. 1992: Sognedannelsen i dansk middelalder. Miljøministeriet, Skov- og Naturstyrelsen 1992.

Christiansen, T. E. 1972: Danmarks middelalder (T. E. Christiansen, red.). København 1972.

Clemmensen, M. 1937: Bulhuse. Studier over gammel dansk Trabygningskunst I-II. København 1937.

Gräslund, A.S. 1992: Kultkontinuitet - myt eller verklighet. Om arkeologins möjligheter att belysa problemet. Bertil Nilsson (red.), Projektet Sveriges kristnande. Publikationer 1. Lunne Böcker. Uppsala 1992.

Hauglid, R. 1994: Fra Urnesdyr til drage. Foreningen til norske fortidsminnesmerkers bevaring. Arbok 1994. Oslo 1994.

Henry, F. 1973: Irish Art during the Viking Invations (800-1200 A.D.). London 1973.

Jeppesen, J. \& H. J. Madsen. 1988-89: Stormandsgård og kirke i Lisbjerg. Kuml 1988-89.

Kornerup, J. 1869: Om den tidlige Middelalders Trækirker i Danmark. Aarbøger for Nordisk Oldkyndighed og Historie 1869.

Krogh, K. J. \& O. Voss. 1961: Fra hedenskab til kristendom i Hørning. Nationalmuseets Arbejdsmark 1961.

Lasco, P. 1972: Ars Sacra 800-1200. Harmondsworth, Penguin 1972.

Liebgott, N.-K. 1989: Dansk middelalderarkacologi. København 1989.

Møller, E. 1953: Romanske tagkonstruktioner. Årbøger for Nordisk Oldkyndighed og Historie 1953.

Møller, E. \& O. Olsen. 1961: Danske trækirker. Nationalmuseets Arbejdsmark 1961.

Norn, O. \& S. Skovgård. 1990: The House of Wisdom. København. 1990.

Nyborg, E. 1979: Enkeltmænd og fællesskaber i organiseringen af det romanske sognekirkebyggeri. Festskrift til Harald Langberg. København 1979

Olsen, O. 1967: Rumindretningen i romanske landsbykirker. Kirkehistoriske samlinger 7. Rakke VI. København 1967.

Petersen, H. 1894: Bygningslevninger af Træe fra Danmarks tidlige Middelalder. Aarboger for Nordisk Oldkyndighed og Historie 1894.

Schmidt, H. 1981: Trelleborghuset og Fyrkathuset. Nationalmuseets Arbejdsmark 1981.

Sveriges kyrkor, Gotland, Garde kirke. 1972.

Sørensen, M.Å., J. Jeppesen \& H. J. Madsen. 1995: Lisbjergkirkens forgænger. Skalk 1995, nr. 3 


\section{The reconstruction of the stave church at Hørning}

When Christianity won through in Denmark late in the Viking period the first churches were erected, built of wood. None actually survive as buildings, but remains of 1()-15 churches have been uncovered, mostly below the floors of stone churches. Although so few have been found, it is clear that many more were built in 11 th century Denmark. We read in Adam of Bremen's description of the Scandinavian countries from about 1(1)7() that there were several hundred churches within the borders of Denmark in his day, and most of them must have been wooden. The construction of stone churches in any appreciable number seems only to have begun at the end of the 11 th century (Moller \& ()lsen 1961, 35). The written sources hardly tell anything of church building before 11()$)$.

At Moesgard the Prehistoric Museum and the University of Aarhus are planning jointly to build a full-scale reconstruction of a stave church from the end of the Viking period. It will be located close to the already existing reconstructions of Viking houses at the museum.

The Danish stave church from Horning near Randers in eastern Jutland was chosen for the project. It was excavated by the National Museum in 196() below the floor of the present Horning church. Its ground plan was clearly visible as a rectangular nave $6 \mathrm{ml}$ long and 4.5 $\mathrm{m}$ wide and a $3.3 \times 33 \mathrm{~m}$ square chancel. Carbonized oakwood in the postholes showed that the little church had been destroyed by fire. The charred posts were so well preserved that in most cases there was reasonably accurate information on the cross-sections of the posts (fig. 1).

As well as the traces under the church we have the famous decorated plank from Horning. It was found when the church was restored in 1887 and was discoveed in the fill of the choir wall (fig. 2). Traces of burning on its back make it likely that it came from the burnt wooden church. In the conflagration layer of that building there was found another small piece of wood with remains of coloration like the painting on the plank (Krogl \& Voss 1961, 17). The likelihood that the plank belonged to the wooden church is further supported by tree-ring dating, which shows that it was felled in 1()6()-7() A.1). (Arkxologiske udgravninger i Danmark 199(), 2.34).

The plank had been part of the hammerbeam below the eaves into which the vertical wall planks had once slotted. On its upper edge there are traces of a notcl, and at one end of the tenon with which it had been secured to a corner-post. (On the bottom edge there is the large groove into which the tops of the wall planks fitted. The outer face of the hammer beam was decorated with characteristic animal slings in Urnes style, framed below by the raised edge of the plank and above by a rope moulding. Some of the original paint survives and shows the background colour to have been black, against which the Urnes beast stood out in a strong yellow, with red eyes, snout, and comb. There is also red on the raised lower edge and red and black alternate on the rope moulding. The inner face of the plank is smooth, and on it a plant tendril is painted in red, yellow, green and black on a white lime background.

The plan of the wooden church and the lucky find in the last century of the piece of hammer beam both tell us a lot about the original church, but by no means solve all problems, so that several decisions will have to be made when it is reconstructed. (One of these decisions is whether to use only the building methods used at the time (so far as we know them), or to resort sometimes to modern teclnology. It is sure that a number of compromises will have to be made if the church is to be built and maintained without excessive expense.

Detailed projecting brings matters into focus that might not otherwise have been thought of, but that is after all the reason for undertaking the task at all. At this stage the architect realized that the fine carved animal sling had functioned rather like a decorated frieze in Classical architecture. Probably the hammer beams of the early decorated churches were commonly decorated in this way, as shown by Irish manuscript illuminations from the 7()()'s, cf. fig. 3 (Henry 1973, colour plate B). However the best surviving representations of small, early, wooden churches are seen on the tops of the great Irish stone crosses of the Viking period (fig. 4). 
The building's most important structural element was the earthfast wall posts. Together with the horizontal hammer and gable beams and the foot beams they gave rigidity in both lengthwise and transverse directions (fig. 5). One reason for the rigidity was that the parts were joined together by very wide tenons, which were themselves held by pegs.

As with the Norwegian stave churches, the nave and choir were made of equal height (Bjerknes 197, fig. 66), so the hammer beam of the choir joins on to the eastern gable beam, which is the best solution both constructionally and architecturally. As the Urnes animal interlace as already said made a frieze all around the church, it is obvious that the hammer beams had to have the same height in both parts of the building, interrupted only by corner posts. In the plan as projected the gable triangles also have frames, in this case formed by the horizontal gable beam and the sloping rafters. Also the gable walls are filled out with wide vertical planks.

The excavation at Horning made it clear that the bottoms of the wall planks had stood in foot timbers. In the upper side of such timbers a groove would have been cut to hold the lower ends of the wall planks.

The outer face of the Horning hammer beam was carved in strong relief, while its inner face was smooth (figs. 2 and 6). The shaping of the wall planks aimed at a similar contrast, i.e. a strong relief effect on the outside, which would be accentuated by shadows cast by the sun, and a smoother inner surface.

The $12 \mathrm{~cm}$ wide notch in the upper edge of the Horning hammer beam is the only evidence we have of the roof construction. Probably truss construction was used, which has the good feature that the trusses only weigh on the walls vertically. In Garde church on Gotland the original Romanesque roof is preserved under the Gothic roof (Alslov et al. 1978). The elegantly shaped Romanesque rafters in this church appear to be re-used timbers and may have come originally from an earlier stave church. In all events they have been C-14 dated to A.1). 94() \pm 10() (Sveriges Kyrkor: Gotland, 288). Trusses of Romanesque type are the best suggestion for the reconstruction of the roof timbering at Horning. A recess on the otherwise smooth inner side of the hammer beam suggests that a ceiling may originally have been nailed on the underside of the beams (fig. 6).

In Garde church part of the Romanesque roof covering also survives. It is made of very large pointed oak shingles, laid on boarding. The ridge, which is crowned by a torus with rope moulding, survives also, and in our projected plan the shingles, boarding, and roof ridge will be copied from the Gotland model.

The black background colour of the hammer beam is our reason for painting the church black with the framing emphasized by raised red edges on the posts similar to those along the lower edges of the hammer beams (fig. 7).

We know nothing of the internal arrangements of the Horning stave church, and no decisions have yet been made how they will be reconstructed. This matter will be taken up when the church has been built.
Jens Jeppesen

Forhistorisk museum Moesgård

Holger Sclmidt

Arkitekt M.A.A.

Oversattelse: David Liversage 